\section{Studia \\ z Filologii Polskiej i Słowiańskiej}

DOI: $10.11649 /$ sfps.2193
Studia z Filologii Polskiej i Słowiańskiej, 56

Warszawa 2021

Article No. 2193

Citation:

Петрова, Т. О. (2021). Проблема жанрової типології рецензій на термінологічні словники. Studia z Filologii Polskiej i Stowiańskiej, 56, Article 2193. https://doi.org/10.11649/sfps.2193

Petrova, T. O. (2021). Problema zhanrovoï typolohiï retsenziĭ na terminolohichni slovnyky. Studia z Filologii Polskiej i Słowiańskiej, 56, Article 2193. https://doi.org/10.11649/sfps.2193

\author{
Тетяна О. Петрова \\ (Харківський національний аграрний \\ університет імені В. В. Докучаєва)
}

\title{
Проблема жанрової типології рецензій на термінологічні словники
}

Жанрова типологія рецензій - складна проблема, що стосується критичного дискурсу, оскільки його центральною категорією $є$ жанр. Поняття дискурсу має в мовознавстві неоднозначні дефініції, 3-поміж яких в аспекті досліджуваного питання спираємося на таку: це «зв'язний текст у контексті багатьох конститувальних і фонових чинників [...]; [...] текст у сукупності соціокультурних, прагматичних, психологічних та інших чинників» (Загнітко, 2012a, с. 206). Отже, дискурс розуміємо як сукупність текстів, об'єднаних спільними рисами. Створений у певний момент й у конкретній ситуації текст наповнюється індивідуальним, особистісним смислом, тобто перетворюється на дискурс. Ураховуючи семасіологічний підхід, дискурс постає текстом, «заплідненим» когнітивною, психологічною, естетичною діяльністю адресата, з’являється з тексту, народжується в ньому; а відповідно до ономасіологічного підходу спочатку виникає дискурс, що із часом перетворюється на текст, який адресат

This is an Open Access article distributed under the terms of the Creative Commons Attribution 3.0 PL License (creativecommons.org/licenses/by/3.0/pl/), which permits redistribution, commercial and non-commercial, provided that the article is properly cited. (c) The Author(s) 2021.

Publisher: Institute of Slavic Studies, Polish Academy of Sciences

[Wydawca: Instytut Slawistyki Polskiej Akademii Nauk] 
знову може трансформувати в дискурс. Тип дискурсу - «клас об’єднаних загальною комунікативною метою текстів, які застосовуються в типових ситуаціях спілкування, мають однакову прагматичну установку та спільні лінгвостилістичні риси» (Карпчук, 2006, с. 11). Підгрунтям виділення типів дискурсу слугують різні критерії. Наприклад, Ірина Шевченко та Олена Морозова виокремлюють значну кількість дискурсивних типів та їхніх підтипів за такими критеріями: 1) урахування форми; 2) адресатне спрямування; 3) умови настанов і комунікативних принципів; 4) соціально-ситуативний параметр; 5) характеристики адресанта й адресата; 6) функційні та інформативні складники; 7) формальні та змістові ознаки у функційно-стильовому аспекті відповідно до жанрів і регістрів мовлення (див.: Шевченко \& Морозова, 2005, сс. 233-236).

Типи дискурсів формують жанри. Рецензія на термінологічний словник $€$ інтегральним жанром, що поєднує ознаки наукової комунікації, мовної критики й джерелознавства, які передбачають експертизу й оцінку спеціальних видань. Відповідно, жанр рецензії може реалізуватися насамперед у критичному дискурсі. І. Шевченко та О. Морозова за наведеними вище численними критеріями, на жаль, не виокремлюють критичного дискурсу (Шевченко \& Морозова, 2005, сс. 233-236). Очевидно, науковці розробляють типологію дискурсів з урахуванням панівних положень у мовознавстві певного періоду, згідно з якими й виділяють ключові дискурси. Однак, критичний дискурс-аналіз активно вивчають зарубіжні дослідники, як-от: Ван Дейк (Van Dijk, 2008), Норман Ферклоу, Рут Водак, М. Мейєр (Fairclough \& Wodak, 1997; Wodak \& Meyer, 2009), Маріам Західді, Фаїза Абдуллах, Джаякаран Мукундан (Jahedi et al., 2014). Зазначені науковці трактують критичний дискурс-аналіз переважно як тип аналітичного дослідження, що вивчає шляхи та методи керування, домінування влади, iii нерівноправності, відтворення в суспільстві, а також супротив тексту й мовлення в соціально-політичному контексті (Van Dijk, 2008, с. 352).

Відповідно до напрацьованої теорії «критичний дискурс-аналіз не досліджує мовний знак як такий, а вивчає соціальні явища, що неодмінно $€$ комплексними, а отже, потребують мульти-дисциплінарного й мультиметодологічного підходу» (Wodak \& Meyer, 2009, с. 3). Як видається, необхідно більшу увагу приділяти критичному дискурсу, предметом аналізу якого $є$ рецензії, зокрема й на термінологічні словники. Момент виникнення першої рецензії на термінографічну працю вважаємо початковою точкою формування дискурсу критики спеціальних словників. 
В українській науковій літературі відомі поодинокі праці, присвячені аналізу окремих підтипів критичного дискурсу. Наприклад, Роман Бубняк досліджує його літературно-критичний підтип (Бубняк, 2001), Ірина Левчук - «рецензійний дискурс» (Левчук, 2013). Необхідність і важливість вивчення критичного дискурсу й розроблення жанрової типології постпублікаційних рецензій на термінологічні словники визначає актуальність цього дослідження, тому мета статті - спроба розроблення жанрової типології постпублікаційних рецензій на термінологічні словники з урахуванням особливостей критичного субдискурсу та вияву категорії оцінки в тексті рецензій такого типу. Наголосімо, що наукову рецензію розглядають переважно як жанр критики літературної та газетно-журнальної публіцистики (ЛЭС, 1987, с. 322), різновид оцінювально-критичного типу текстів (Хомутова \& Кравцова, 2014, с. 71), оцінювальний жанр (Кравцова, 2015, с. 862), «жанр, що стосується металексикографічного дискурсу й підвищує словникову культуру певного суспільства» (Bergenholtz \& Gouws, 2016, с. 60), як мовленнєвий жанр з оцінювальними судженнями (Антоненко, 2011, с. 3), «єдиний жанр, покликанням якого $€$ оцінювання наукових творів» (Гуманенко, 2015, c. 15). Ключовим у визначенні жанру рецензії $€$ критерій оцінки. Поняття «критика» й «оцінка» в лінгвістиці розглядають як абсолютні синоніми. 3’ясуймо, наскільки критичний дискурс може бути оцінювальним.

На основі прагматичного чинника виокремлюють оцінний дискурс та оцінний субдискурс: «глобальна аксіологічна макростратегія та обов’язкові аксіологічні тактики формують оцінний дискурс як самодостатній тип дискурсу, а факультативні аксіологічні тактики у різноманітних комунікативних стратегіях дозволяють виділити оцінний субдискурс у межах дискурсів різних типів (політичного, рекламного, педагогічного, ксенофобічного, наукового, ритуального тощо)» (Краснобаєва-Чорна, 2010, c. 216). У цьому переліку поряд з педагогічним і науковим дискурсами значно вирізняється за своєю суттю ксенофобічний дискурс. Сьогодні він $€$ феноменом, що формують політичні, соціальні, національні, релігійні чинники, а головно національний складник. Ксенофобічний дискурс потребує спеціального вивчення, оскільки він тісно переплітається з дослідженням етнічної картини світу, для якої визначальним $\epsilon$ механізм етнодиференціаціі. Зосереджуючи увагу на оцінці художнього дискурсу, Надія Миронова виділяє критичний дискурс (книжну критику) в структурі оцінювального дискурсу (Миронова, 1998): у системі оцінювального 
дискурсу вона виокремлює чотири субдискурси - критичний, рекламний, політичний і юридичний.

Зауважмо, сьогодні в науковій літературі функціюють, як бачимо, терміни-варіанти оцінний дискурс і оцінювальний дискурс. Це визначає необхідність їхнього зведення до єдиної форми. Уважаємо, що одиницю оцінний доречно використовувати для утворення найменування на позначення понять, що вказують на те, що у їхньому значенні вже вказана оцінка кого-, чого-небудь, напр.: оцінна вартість, оцінний лист, оцінний тон, оцінна лексика та ін. Для понять, у значенні яких визначаються якість, цінність, значимість, вартість кого-, чого-небудь, необхідно вживати одиницю оцінювальниц̆, порівн. оцінювальна комісія. Відповідно, на позначення дискурсу, що реалізується в критичних публікаціях, у яких здійснено оцінювальні дії, зокрема експертування якості термінологічних словників і оприлюднено оцінку їхньої значимості й цінності, доречно використовувати терміноодиницю оцінювальний дискурс.

Отже, критичний субдискурс й оцінювальний дискурс не тотожні, оскільки вони належать до різних рівнів системи. Оиінювальний дискурс розуміють як «семантичний комплекс, представлений у комунікативно-цільових текстах, побудованих на аксіологічних стратегіях» (Миронова, 1998). Авторка цієї статті підтримує доцільний принцип розмежування оцінювального дискурсу та критичного субдискурсу, а також спирається на пояснення Жанни Краснобаєвої-Чорної сутності процесу формування оцінювального дискурсу й субдискурсу. Критичний субдискурс у вузькому значенні розуміємо як (1) сукупність рецензій на термінологічні словники; у широкому - як (2) експертування якості словника із застосуванням критичного підходу, тобто не підрахунку недоліків і помилок у ньому, а оцінювання видання за алгоритмом поетапного аналізу його структур і їхніх параметрів (див. про це: Петрова, 2018а, c. 212). При цьому критика словників «не суперниця» термінографіï: її покликання - розробити інваріантну модель термінологічного словника комплексного типу, що дасть змогу всебічно й різнорівнево репрезентувати термінологію окремої сучасної галузі та її підгалузей. Важлива особливість критичного субдискурсу - можливість ведення діалогу чи полеміки між його автором та експертом стосовно оцінки словника. Типовими виявами оцінювального дискурсу й критичного субдискурсу постають рецензії на наукові праці - різного типу словники, монографії та ін. Під час з’ясування якості, цінності й значимості 
спеціального видання в межах критичного дискурсу актуалізуються аксіологічні стратегії.

Лінгвістичні термінологічні словники пропонують таке визначення категорії оцінки:

1) аспект семантики мовних висловів; відображення в мовних структурах особливостей членування мовцями об'єктивного світу за його ціннісними параметрами - «добро» або «зло», «користь» або «шкода», «позитивне» чи «негативне» та ін.; 2) судження мовця, його відношення - «схвалення» або «несхвалення», «заохочення» тощо - як складник стилістичної конотації (Загнітко, 2012b, с. 349).

Тетяна Космеда стверджує, що «оцінка є текстовою категорією і має функційно-комунікативну спрямованість», а також зауважує, що вона

створює інтенсіональний контекст «текст у тексті». Оцінка $є$ певним «модусом» означення ситуації, і сама характеризується різними модальностями. По-перше, оцінка може бути репрезентована різним ступенем категоричності, по-друге, вона може маніфестуватися в модусах бажання, необхідності, примусу, по-третє, вона може виступати в модусі об’єктивної оцінки, а може об’єкивуватися, пропонуватися як спільна, загальна думка тощо (Космеда, 2000, с. 289).

Розрізняють такі види оцінки: 1) позитивна/негативна/нейтральна; 2) загальна/приватна; 3) об’єктивна/суб'єктивна; 4) емоційна/раціональна/ емоційно-раціональна; 5) абсолютна/порівняльна (див про це, напр.: Бєссонова, 2002, с. 124). Категорію оцінки розглядають як багатоаспектне поняття (логіко-семантичне, мовностилістичне, когнітивне, семантико-прагматичне, функційно-граматичне). Вона передбачає вияв думки про рецензоване видання й репрезентується в тексті оцінними судженнями, тому вважаємо її одним із жанроутворювальних чинників.

Традиційно архітектоніку жанру рецензії створюють такі елементи: заголовок, бібліографічний опис словника, вступ, основна частина, висновок. Зміст різновиду рецензії на термінографічне видання відрізняється від літературознавчої чи мовознавчої рецензій. Кожен елемент такого типу тексту $€$ «закономірним етапом в оцінній характеристиці рецензійної публікації, має певну прагматичну настанову й отримує в тексті рецензії відповідне змістовне та графічне оформлення» (Левчук, 2014, с. 143).

Жанрова особливість спеціального видання (його тип - словник термінів, перекладний, дефінітивний, дефінітивно-перекладний, орфо- 
графічний; короткий, великий; електронний, паперовий) і його будова визначають зміст та обсяг структурних компонентів рецензії на нього. Інваріантна модель словника (зокрема дефінітивного) повинна містити такі параметри: на рівні мегаструктури (загальної побудови) - передмову, інструкцію з користування, додатковий матеріал, джерела, абетковий покажчик за сферами знань; макроструктури - реєстр термінів словника; мікроструктури (терміностатті) - заголовний термін, варіанти, акцентну характеристику, початкову форму заголовного терміна, граматичну характеристику, етимологічну довідку, дефініцію, енциклопедичну інформацію, системні відношення (див. докладно: Петрова, 2018b, сc. 140-145). Критик словника спирається на теоретичне підгрунтя видання - передмову (чи не найголовніший параметр), де передбачено зазначати тип видання, розкрити засади його укладання, пояснити вибір принципів лексикографічних параметрів. Утім, за авторськими спостереженнями, не в усіх словниках вони репрезентовані. У разі їхньої відсутності критик самостійно визначає тип видання, з'ясовує, які параметри використані в ньому, оцінює їх. Отже, що краща, добре обміркована передмова, у якій автор розкриває принципи й засади побудови спеціальної праці й указує на труднощі, з якими він зіткнувся, то й вища якість словника.

Теорія критики й теорія дискурсу взаємодіють 3 метою вивчення структури оцінок, засобів їхнього вираження та аргументації. Проаналізувавши сучасні рецензії на наукові праці, Жанна Краснобаєва-Чорна виділяє два типи аксіологічних тактик у дискурсивній практиці. Це тактики «1) продукування оцінного значення (позитивного/негативного), що використовуються адресантом як суб'єктом оцінювання; 2) реагування на оцінне значення (позитивне/негативне), що пов'язане з адресатом як об'єктом продукування оцінювання» (Краснобаєва-Чорна, 2010, с. 216). Виокремлено також три структурні типи оцінного дискурсу (його розуміємо як критичний субдискурс):

I. 1. Вступ (оцінка (+/-) / нейтральна (анотований вступ)) - обов’язковий компонент. 2. Основна частина (оцінка (+/-)) - обов'язковий компонент. 3. Висновок (оцінка (+/-)) - обов’язковий компонент. 4. Література - факультативний компонент. II. 1. Епіграф/Анотація - факультативний компонент. 2. Вступ (оцінка (+/-) / нейтральна) - обов’язковий компонент 3. Основна частина складається з двох окремих блоків: оцінка (+), оцінка (-) - обов’язковий компонент. 4. Висновок (оцінка (+)) - обов’язковий компонент. III. 1. Вступ 
(оцінка (+)) - обов’язковий компонент. 2. Основна частина (оцінка (+)) обов'язковий компонент. 3. Висновок (оцінка $(+))$ - обов'язковий компонент (Краснобаєва-Чорна, 2010, с. 217).

Як бачимо, зміст компонентів структурних типів рецензій містить позитивну, негативну чи нейтральну оцінки. Ж. Краснобаєва-Чорна зауважує:

здебільшого негативна оцінка значно менша за позитивну і становить приблизно від 5 \% до 30 \% тексту рецензії. Позитивна та негативна оцінки об’єкта супроводжуються аргументацією [...]; негативна оцінка може додатково виділятися за допомогою графічних засобів курсиву або підкреслення [...]; поряд з аргументацією негативної оцінки логічним $€$ прийом порівняння з попереднім виданням або іншим джерелом [...]; іноді негативна оцінка пом'якшується певними припущеннями рецензента щодо її причин, внаслідок чого створюється ефект одночасного виправдання негативної оцінки [...], яка додатково може ще супроводжуватися позитивною оцінкою [...] (Краснобаєва-Чорна, 2010, с. 217).

Спираючись на викладене вище та на визначення поняття «критерій оцінки» («денотативна роль ситуантного типу, особа, предмет, вияв, щодо якого/яких встановлюються відповідність/невідповідність певних параметрів, обставин, призначення [...]» Загнітко, 2012b, с. 113), доходимо висновку, що основу оцінки спеціальної праці формують: позиція рецензента, факти, що спонукають до схвалення, невизнання, ігнорування певних принципів репрезентування параметрів видання.

Аналізування термінографічної продукції допускає вияв авторської індивідуальності, що зумовлений суб'єктивністю поглядів критика, його почуттями й уявленнями про норму/стереотип. Основою об'єктивної оцінки є поняття «істинність - хибність» і суспільний досвід. Значну роль відіграють досвід і фахова компетенція критика, його упередження, морально-етичні установки та особистісні якості. Категорія оцінки має суб'єктивно-об’єктивну сутність, що визначає її міжрівневий статус, комплекс засобів вираження. Функційна категорія оцінки в критичному субдискурсі - це організований оцінний комплекс різних рівнів, поєднаних аксіологічним значенням.

Не всі види оцінок реалізуються під час експертування термінографічних видань, що засвідчує аналіз текстів рецензій: здебільшого словникові параметри оцінюють позитивно чи негативно, меншою мірою - порівнюють способи їхнього репрезентування в інших словни- 
ках. Часто поза розглядом залишаються компоненти, без яких уявлення про працю такого типу буде неповним. Натомість оцінка критичного субдискурсу має особливий характер - підкреслено критичний, тому вона повинна бути передусім об'єктивною, комплексною, конкретною та конструктивною, оскільки за їі результатами судять про рівень розвитку національної термінографії на певному етапі ії розвитку.

Вагомий внесок у визначення й розвиток теорії мовленнєвого жанру, як відомо, належить Михайлу Бахтіну, який номінує мовленнєві жанри «відносно стійкими типами висловлювань» (Бахтин, 1997, с. 159). Типологізування мовленнєвих жанрів ускладнюється взаємодією жанрознавства із суміжними дисциплінами. Найпоширеніша класифікація мовленнєвих жанрів базується на двох головних параметрах класифікації: 1) виділення первинних і вторинних жанрів; 2) розмежування стандартизованих і вільних мовленнєвих жанрів. Істотні відмінності між первинними та вторинними мовленнєвими жанрами виникають в умовах більш складного й відносно високорозвиненого культурного спілкування. Первинні жанри - це прості, а вторинні - складні (див.: Бахтин, 1997, c. 161). Вираження оцінки в рецензійних текстах тісно пов'язане з їхньою жанровою варіантністю. Елеонора Лассан також розглядає рецензію як «тип мовних актів, інваріантні ознаки яких дають змогу говорити про особливості жанру рецензії як вторинного» (Лассан, 2012).

Вивченню різних аспектів наукової рецензії - з'ясуванню мовностилістичних особливостей оформлення, специфіки побудови ії інтегральної моделі, характеристики як аналітичного й публіцистичного жанру одночасно, комунікативно-прагматичних параметрів її тексту - присвячують праці українські дослідники (Олександра Гуманенко (Гуманенко, 2011), Левчук, 2013; Наталія Mex (Mex, 2017), Світлана Яворська (Яворська, 2000), Ніна Яценко (Яценко, 2017)) та зарубіжні науковці (Хеннінг Бергенхольц і Руфус Х. Гаус; Bergenholtz \& Gouws, 2016; Лассан, 2012; Борис Степанов (Степанов, 2016), Маргарита Чернишова (Чернышева, 2011), В’ячеслав Щербін (Щербин, 2007)). О. Гуманенко, наприклад, стверджує, що «серед інших жанрів наукової літератури рецензія займає особливе місце» (Гуманенко, 2015, с. 15). Вона переконана: «для того, щоб наукова рецензія, яка має такі глибокі витоки, нарешті зайняла достойне місце серед інших жанрів наукової періодики, необхідно пам'ятати, що рецензія на будь-яких етапах свого існування повинна відповідати потребам не лише наукової спільноти, а й суспільства загалом» (Гуманенко, 2015, с. 18). Аналізуючи сучасні погляди на місце рецензії серед інших 
наукових текстів, відзначмо, що иії розглядають як «науково-оцінний», «суто теоретичний», «внутрішньоінституційний» тип (див.: Филиппов et al., 2019, сc. 107-109), що свідчить про міждисциплінарний характер жанру рецензіi, іii синкретизм. Розмаїття типів (жанрів) рецензії відстежуємо в журналістиці й літературознавстві, порівн.: анотація, коротка рецензія (відгук), реферативна рецензія, звичайна газетна (журнальна) рецензія, проблемна рецензія, рецензія-есе, рецензія-діалог, рецензія-фейлетон, рецензія-памфлет, рецензіяжарт, рецензія-лист, авторецензія, рецензентська репліка (ЛСД, 1997, с. 242). Наприклад, внутрішньожанровими різновидами журналістської рецензії $\epsilon$ анотаційна рецензія (передбачає малі розміри, описовість, популяризацію літературного матеріалу), відкритий лист (містить звернення, бесіду з адресатом), аналітична рецензія (порівняно великий розмір, витлумачення твору, оцінка його місця в літературному процесі). Однак

сучасна українська критика виходить за рамки якогось певного жанру, а за обсягом критичного виступу має такі головні форми: велика критика (монографії, дисертації, нариси, книги-біографії, портрети, статті, огляди, автореферати), мала критика (анотації, рецензії, відгуки), літературно-критична замітка та закрита критика (зокрема, видавниче рецензування) (Яворська, 2000, сс. 6-7).

\section{Відстежено, що}

за функцією англомовна наукова (науково-теоретична та науково-популярна) рецензія поділяється на такі головні підвиди: академічна рецензія на наукову працю та рецензія на працю технічного профілю, реферативна рецензія, звичайна і стисла рецензія на літературні та інші новинки у спеціалізованих (природничих і технічних) виданнях (Яворська, 2000, с. 8).

Аналізуючи типологійну характеристику рецензій на наукові тексти, О. Гуманенко виділяє постпублікаційні (одержали видавниче втілення) та допублікаційні (виокремлено такі підтипи: 1) внутрішньовидавнича, або «редакторська» (пишеться редактором); 2) зовнішньовидавнича, або «експертна» (пишеться рецензентом, тобто експертом); 3) супровідна (оцінювання наукового тексту для подальшого його публікування) зовнішня і внутрішня), а також виділяє об'ємні, стислі й мінірецензії (Гуманенко, 2011, сс. 120-121). Тут широко репрезентовано підтипи допублікаційної рецензії, однак обділено увагою жанровий різновид постпублікаційні рецензії. Отже, жанрове типологізування постпублікаційних рецензій на спеціальні словники до цього часу не здійснено, що передусім і визначає новизну цього дослідження. Зауважмо, що базовий жанр укра- 
їнської термінографічної критики - рецензія - теж вирізняється жанровою неоднорідністю. Не всі перераховані вище жанрові різновиди рецензій на наукові тексти можна «накласти» на рецензії на термінологічний словник. Якщо спроєктувати журналістські, літературознавчі, публіцистичні та інші жанрові різновиди рецензій на жанр словника як науковий текст, то зреалізуються такі типи: анотаційна рецензія, коротка рецензія, реферативна рецензія, рецензія-діалог, рецензентська репліка, аналітична рецензія та ін.; а залишаться - рецензія-есе, рецензія-фейлетон, рецензія-памфлет, рецензія-жарт, рецензія-лист, відкритий лист, авторецензія.

Авторка цієї розвідки проаналізувала 50 рецензій на термінологічні словники, що опубліковані в українській науковій періодиці і становлять корпус текстів критичного субдискурсу. Безперечно, доцільно розробляти типологію (класифікацію) постпублікаційних рецензій на спеціальні видання, застосовуючи ознаки виділення жанрових типів (різновидів) рецензій, зокрема на підставі проведеного аналізу структури й змісту рецензій на термінологічні словники пропонуємо їхню загальну багатоаспектну жанрову типологію за такими ознаками:

1) кількість авторів -

а) одноосібна (за фахом рецензентів - рецензії галузевих фахівців і рецензії мовознавців або термінографів);

б) колективна (рецензія представників одного фаху й рецензія представників різного фаху);

2) тип журналу, у якому вміщено рецензію, -

а) академічний або неакадемічний (науково-популярний) рівень;

б) спосіб репрезентації інформації - паперові й електронні;

3) обсяг інформації -

а) мінірецензії (рецензія-репліка/флешрецензія/бліцрецензія та рецензія-анотація);

б) стислі рецензії (рецензія-відгук);

в) розгорнуті рецензії (рецензія-стаття аналітичного характеру);

4) кількість розглядуваних словників у рецензії монорецензія й полірецензія, або рецензія-огляд;

5) тип розглядуваних спеціальних словників у рецензії -

a) характер носія інформації (рецензії на паперові словники й на електронні словники); 
б) спосіб семантизування термінів (енциклопедичні видання, дефінітивні, перекладні словники чи довідники);

в) походження (місце створення) аналізованого словника (рецензії на національні словники чи українськомовні словники, українські російськомовні словники і рецензії українських критиків на зарубіжні словники);

6) наявність/відсутність наукової дискусії, тобто наявність/відсутність відповіді на рецензію -

рецензії, що отримали відповідь, і рецензії, що не отримали відповіді автора словника;

7) стиль викладу тексту в рецензії -

власне наукові, науково-популярні, ідіостильові;

8) час реагування на вихід у світ словника -

синхронні й відтерміновані.

Отже, укладено універсальну жанрову типологію рецензій на термінологічні словники, що є відкритою. Із часом можуть актуалізуватися нові параметри й нові типи рецензій. Під час визначення типу рецензії на термінологічний словник важливо враховувати всі названі вище ознаки, щоб кожна критична публікація відповідала статусу універсальної (комбінованого типу). Система особливостей жанру рецензії сприяє кращому оцінюванню спеціального видання, його панорамному баченню.

Постпублікаційна рецензія на термінологічні словники - інтегральний жанр, що поєднує ознаки наукової комунікації, мовної критики, джерелознавства, літературознавства й публіцистики. Вона має потужний потенціал функціювати як самодостатній і самостійний текст, впливати на розвиток критичного субдискурсу. Критичний субдискурс - підтип оцінювального дискурсу. Категорія оцінки виконує важливу жанроутворювальну функцію, що репрезентується в тексті рецензії оцінними судженнями. Найбільш часто параметри мега-, макро- й мікроструктури словника оцінюють позитивно чи негативно, меншою мірою - порівнюють способи їхнього репрезентування в інших словниках, почасти поза розглядом залишаються параметри, без яких уявлення про працю такого типу буде неповним.

Сучасний науковий дискурс потребує активного рецензування, посиленої уваги критиків. Українському критичному субдискурсові бракує аргументованих текстів зі змістовною критичною оцінкою параметрів макро- й мікроструктури термінологічного словника і пропозицій сто- 
совно застосування інваріантних способів та принципів репрезентування термінологї як різнорівневої системи знань. Об'єктивність, комплексність, конкретність і конструктивність критики словників сприятимуть ефективному розвитку критичного субдискурсу, а насамперед національної термінографії.

\section{Скорочення}

ЛСД - Літературознавчий словник-довідник (Гром’як \& Ковалів, 1997).

ЛЭС - Литературный энциклопедический словарь (Кожевникова \& Николаева, 1987).

\section{Бібліографія}

Антоненко, Ю. (2011). Оценочные суждения в жанре научной рецензии. In Теоретичні та прикладні питання філологіі: Матеріали II Міжнародної наукової конференції (pp. 3-11). Дніпродзержинський державний технічний університет.

Бахтин, М. (1997). Проблема речевых жанров. In М. Бахтин, Собрание сочинений в 7 томах (Vol. 5, pp. 159-206). Русские словари.

Бєссонова, О. (2002). Оцінний тезаурус англійської мови: Когнітивно-гендерні аспекти. Донецький національний університет.

Бубняк, Р. (2001). Літературно-критичний дискурс: Сутність, структура, засоби вираження [Summary of doctoral dissertation]. Тернопільський державний педагогічний університет ім. В. Гнатюка.

Гром’як, Р., \& Ковалів, Ю. (Eds.). (1997). Літературознавчий словник-довідник [ЛСД]. Видавничий центр “Академія”.

Гуманенко, О. (2011). Особливості типологічної характеристики рецензій на наукові твори. Наукові записки, 2011(3), 119-126.

Гуманенко, О. (2015). Місце рецензії в історії наукової періодики. Наукові записки Української академії друкарства: Соціальні комунікації, 2015(1), 15-20.

Загнітко, А. (2012а). Словник сучасної лінгвістики: Поняття і терміни (Т. 1). Донецький національний університет.

Загнітко, А. (2012b). Словник сучасної тінгвістики: Поняття і терміни (Т. 2). Донецький національний університет.

Карпчук, Н. (2006). Адресованість в офіиійному та неофіційному англомовному дискурсі: Комунікативно-прагматичний аналіз. РВВ “Вежа” Волинського державного університету ім. Лесі Українки. 
Тетяна О. Петрова Проблема жанрової типології рецензій на термінологічні словники

Кожевникова, В., \& Николаева, П. (Eds.). (1987). Литературный энииклопедический словарь [ЛЭС]. Советская энциклопедия.

Космеда, Т. (2000). Аксіологічні аспекти прагмалінгвістики: Формування і розвиток категорії оцінки. Львівський національний університет ім. Івана Франка.

Кравцова, Е. (2015). Научная рецензия: Социально-ориентированная лексика. In С. Баулин (Еd.), Наука Южно-Уральского государственного университета: Материаль 67-й научной конференции: Секция сочиально-гуманитарных наук (pp. 860-867). Издательский центр Южно-Уральского государственного университета.

Краснобаєва-Чорна, Ж. (2010). Структурні типи оцінного дискурсу: На матеріалі сучасних україномовних рецензій. Лінгвістичні студіи: Збірник наукових прац, , 20, 216-222.

Лассан, Э. (2012). Рецензия как жанр и как речевой акт. In Г. Солганик, Н. Клушина, В. Славкин, \& Н. Смирнова (Eds.), Лингвистика речи, медиастилистика: Коллективная монография, посвященная 80-летию профессора Григория Яковлевича (рp. 190-206). Флинта; Наука.

Левчук, I. (2013). Комунікативні ознаки рецензійного дискурсу. Studia Ukrainica Posnaniensia, 2013(1), 99-107.

Левчук, I. (2014). Комунікативно-прагматичні параметри рецензійного тексту. In I. Левчук (Еd.), Волинь білологічна: Текст і контекст: Лінгвостилістика ХХІ століття: Стан і перспективи: Збірник наукових праць (Vol. 17, pp. 139-151). Східноєвроп. нац. ун-т ім. Лесі Українки.

Mex, Н. (2017). Жанросфера сучасної української наукової комунікації. Мова і міжкультурна комунікація, 2017(1), 64-73.

Миронова, Н. (1997). Политический дискурс vs оценочный дискурс. In Ю. Сорокин \& В. Базылев (Eds.), Политический дискурс в России: Материаль рабочего совещзания 30 марта 1997 г. (рр. 41-50). Институт языкознания РАН; Высшие молодежные курсы.

Миронова, Н. (1998). Структура оценочного дискурса [Summary of doctoral dissertation]. Московский государственный лингвистический университет.

Петрова, Т. (2018а). Українська термінографічна критика: Від витоків до сучасності. Науковий вісник Національного університету біоресурсів і природокористування Украӥни: Філологічні науки, 292, 208-217.

Петрова, Т. (2018b). Фітомеліоративна термінологія сучасної украӥнської мови та ї відображення в термінологічному словнику комбінованого типу. ТОВ “ТПГ”.

Степанов, Б. (2016). “Кризис жанра”: Книжные рецензии в перспективе исследований научной коммуникации. Laboratorium, 2016(8(1)), 82-106.

Филиппов, К., Копчук, Л., \& Григорьева, Л. (Eds.). (2019). Немецкая филология в СанктПетербургском государственном университете: Vol. 8. Типология речевых жанров. Издательство Санкт-Петербургского университета.

Хомутова, Т., \& Кравцова, Е. (2014). Научная рецензия: Интегральный подход. Язык и культура, 2014(1(25)), 70-76. 
Тетяна О. Петрова Проблема жанрової типології рецензій на термінологічні словники

Чернышова, М. (2011). Параметры лексикографической критики. Слово и словарь: Vocabulum et vocabularium, 2011(12), 7-10.

Шевченко, I., \& Морозова, О. (2005). Проблеми типології дискурсу. In I. Шевченко (Ed.), Дискурс як когнітивно-комунікативний феномен (рр. 233-236). Константа.

Щербин, В. (2007). Вклад О. Н. Трубачева в развитие научной критики словарей. Bопросы языкознания, 2007(5), 3-21.

Яворська, С. (2000). Рецензія як тип тексту: На матеріалі англомовної рецензї [Summary of doctoral dissertation]. Львівський національний університет ім. Івана Франка.

Яценко, Н. (2017). Жанрово-стильова специфіка наукової рецензії. Українська мова, 2017(1), 92-101.

Bergenholtz, H., \& Gouws, R. H. (2016). On the metalexicographic genre of dictionary reviews, with specific reference to LexicoNordica and Lexikos. Lexikos, 26, 60-81. https://doi.org /10.5788/26-1-1358

Fairclough, N., \& Wodak, R. (1997). Critical discourse analysis. In T. van Dijk (Ed.), Discourse studies: A multidisciplinary introduction (Vol. 2, pp. 258-284). Sage.

Jahedi, M., Abdullah, F. S., \& Mukundan, J. (2014). An overview of focal approaches of critical discourse analysis. International Journal of Education and Literacy Studies, 2(4), 28-34. https://doi.org/10.7575/aiac.ijels.v.2n.4p.28

Van Dijk, T. A. (2008). Critical discourse analysis. In D. Schiffrin, D. Tannen, \& H. E. Hamilton (Eds.), The handbook of discourse analysis (pp. 352-371). Blackwell Publishing.

Wodak, R., \& Meyer, M. (2009). Critical discourse analysis: History, agenda, theory, and methodology. In R. Wodak, \& M. Meyer (Eds.), Methods for critical discourse analysis (pp. 1-33). Sage. Retrieved July 3, 2019, from: https://us.corwin.com/sites/default/files /upm-binaries/24615_01_Wodak_Ch_01.pdf

\section{Bibliography (Transliteration)}

Antonenko, IU. (2011). Otsenochnye suzhdeniia v zhanre nauchnoŭ retsenzii. Teoretychni ta prykladni pytannia filolohii: Materialy II Mizhnarodnoï naukovoï konferentsï (pp. 3-11). Dniprodzerzhyns'kyı̆ derzhavnyı̆ tekhnichnyı̆ universytet.

Bakhtin, M. (1997). Problema rechevykh zhanrov. In M. Bakhtin, Sobranie sochineniǔ $v 7$ tomakh (Vol. 5, pp. 159-206). Russkie slovari.

Bergenholtz, H., \& Gouws, R. H. (2016). On the metalexicographic genre of dictionary reviews, with specific reference to LexicoNordica and Lexikos. Lexikos, 26, 60-81. https://doi.org /10.5788/26-1-1358

Biessonova, O. (2002). Otsinnyı̆ tezaurus anhlǐ̌s'koï movy: Kohnityvno-henderni aspekty. Donets'kyı̆ natsional'nyı̆ universytet. 
Bubniak, R. (2001). Literaturno-krytychnyı̆ dyskurs: Sutnist', struktura, zasoby vyrazhennia [Summary of doctoral dissertation]. Ternopil's'kyı̆ derzhavnyı̌ pedahohichnyĭ universytet im. V. Hnatiuka.

Chernyshova, M. (2011). Parametry leksikograficheskoü kritiky. Slovo i slovar': Vocabulum et vocabularium, 2011(12), 7-10.

Fairclough, N., \& Wodak, R. (1997). Critical discourse analysis. In T. van Dijk (Ed.), Discourse studies: A multidisciplinary introduction (Vol. 2, pp. 258-284). Sage.

Filippov, K., Kopchuk, L., \& Grigor'eva, L. (Eds.). (2019). Nemetskaia filologiia v SanktPeterburgskom gosudarstvennom universitete: Vol. 8. Tipologiia rechevykh zhanrov. Izdatel'stvo Sankt-Peterburgskogo universiteta.

Hrom'iak, R., \& Kovaliv, IU. (Eds.). (1997). Literaturoznavchyı̆ slovnyk-dovidnyk [LSD]. Vydavnychyı̆ tsentr "Akademiia".

Humanenko, O. (2011). Osoblyvosti typolohichnoï kharakterystyky retsenziï na naukovi tvory. Naukovi zapysky, 2011(3), 119-126.

Humanenko, O. (2015). Mistse retsenziï v istoriï naukovoï periodyky. Naukovi zapysky Ukraïns'koï akademiï drukarstva: Sotsial'ni komunikatsiï, 2015(1), 15-20.

IAtsenko, N. (2017). Zhanrovo-styl'ova spetsyfika naukovoï retsenziï. Ukrä̈ns'ka mova, 2017(1), 92-101.

IAvors'ka, S. (2000). Retsenziia iak typ tekstu: Na materiali anhlomovnoï retsenziï [Summary of doctoral dissertation]. L'vivs'kyı̆ natsional'nyı̆ universytet im. Ivana Franka.

Jahedi, M., Abdullah, F. S., \& Mukundan, J. (2014). An overview of focal approaches of critical discourse analysis. International Journal of Education and Literacy Studies, 2(4), 28-34. https://doi.org/10.7575/aiac.ijels.v.2n.4p.28

Karpchuk, N. (2006). Adresovanist' v ofitsĭ̌nomu ta neofitsiัnomu anhlomovnomu dyskursi: Komunikatyvno-prahmatychnyı analiz. RVV "Vezha” Volyns'koho derzhavnoho universytetu im. Lesi Ukraïnky.

Khomutova, T., \& Kravtsova, E. (2014). Nauchnaia retsenziia: Integral'nyı̆ podkhod. IAazyk i kul'tura, 2014(1(25)), 70-76.

Kosmeda, T. (2000). Aksiolohichni aspekty prahmalinhvistyky: Formuvannia i rozvytok katehorii otsinky. L'vivs'kyı̆ natsional'nyı̆ universytet im. Ivana Franka.

Kozhevnikova, V., \& Nikolaeva, P. (Eds.). (1987). Literaturnyĭ èntsiklopedicheskiǔ slovar' [LĖS]. Sovetskaia èntsiklopediia.

Krasnobaieva-Chorna, Zh. (2010). Strukturni typy otsinnoho dyskursu: Na materiali suchasnykh ukraïnomovnykh retsenziı̌. Linhvistychni studii: Zbirnyk naukovykh prats', 20, 216-222.

Kravtsova, E. (2015). Nauchnaia retsenziia: Sotsial'no-orientirovannaia leksika. In S. Baulin (Ed.), Nauka IUzhno-Ural'skogo gosudarstvennogo universiteta: Materialy 67-ı̌ nauchno konferentsii: Sektsiia sotsial'no-gumanitarnykh nauk (pp. 860-867). Izdatel'skiŭ tsentr IUzhno-Ural'skogo gosudarstvennogo universiteta.

Lassan, Ė. (2012). Retsenziia kak zhanr i kak rechevoĭ akt. In G. Solganik, N. Klushina, V. Slavkin, \& N. Smirnova (Eds.), Lingvistika rechi, mediastilistika: Kollektivnaia monografiia, posviashchennaia 80-letiiu professora Grigoriia IAkovlevicha (pp. 190-206). Flinta; Nauka. 
Тетяна О. Петрова Проблема жанрової типології рецензій на термінологічні словники

Levchuk, I. (2013). Komunikatyvni oznaky retsenziŭnoho dyskursu. Studia Ukrainica Posnaniensia, 2013(1), 99-107.

Levchuk, I. (2014). Komunikatyvno-prahmatychni parametry retsenziünoho tekstu. In I. Levchuk (Ed.), Volyn' filolohichna: Tekst $i$ kontekst: Linhvostylistyka XXI stolittia: Stan i perspektyvy: Zbirnyk naukovykh prats' (Vol. 17, pp. 139-151). Skhidnoievrop. nats. un-t im. Lesi Ukraïnky.

Mekh, N. (2017). Zhanrosfera suchasnoï ukraïns'koï naukovoï komunikatsiï. Mova i mizhkul'turna komunikatsiia, 2017(1), 64-73.

Mironova, N. (1997). Politicheskiŭ diskurs vs otsenochnyı̆ diskurs. In I. Sorokin \& V. Bazylev (Eds.), Politicheskil diskurs $v$ Rossii: Materialy rabochego soveshchaniia 30 marta $1997 \mathrm{~g}$. (pp. 41-50). Institut iazykoznaniia RAN; Vysshie molodezhnye kursy.

Mironova, N. (1998). Struktura otsenochnogo diskursa [Summary of doctoral dissertation]. Moskovskiı̆ gosudarstvennyı̆ lingvisticheskiŭ universitet.

Petrova, T. (2018a). Ukraïns'ka terminohrafichna krytyka: Vid vytokiv do suchasnosti. Naukovyı visnyk Natsional'noho universytetu bioresursiv i pryrodokorystuvannia Ukraïny: Filolohichni nauky, 292, 208-217.

Petrova, T. (2018b). Fitomelioratyvna terminolohiia suchasnoï ukraïns'koï movy ta ï vidobrazhennia $v$ terminolohichnomu slovnyku kombinovanoho typu. TOV "TPH".

Shcherbin, V. (2007). Vklad O. N. Trubacheva v razvitie nauchnoŭ kritiki slovareı̆. Voprosy iazykoznaniia, 2007(5), 3-21.

Shevchenko, I., \& Morozova O. (2005). Problemy typolohii dyskursu. In I. Shevchenko (Ed.), Dyskurs iak kohnityvno-komunikatyvny̌̆ fenomen (pp. 233-236). Konstanta.

Stepanov, B. (2016). "Krizis zhanra”: Knizhnye retsenzii v perspektive issledovaniŭ nauchnoĭ kommunikatsii. Laboratorium, 2016(8(1)), 82-106.

Van Dijk, T. (2008). Critical discourse analysis. In D. Schiffrin, D. Tannen, \& H. E. Hamilton (Eds.), The handbook of discourse analysis (pp. 352-371). Blackwell Publishing.

Wodak, R., \& Meyer, M. (2009). Critical discourse analysis: History, agenda, theory, and methodology. In R. Wodak, \& M. Meyer (Eds.), Methods for critical discourse analysis (pp. 1-33). Sage. Retrieved July 3, 2019, from: https://us.corwin.com/sites/default/files /upm-binaries/24615_01_Wodak_Ch_01.pdf

Zahnitko, A. (2012a). Slovnyk suchasnoï linhvistyky: Poniattia i terminy (T. 1). Donets'kyı̌ natsional'nyı̆ universytet.

Zahnitko, A. (2012b). Slovnyk suchasnoï linhvistyky: Poniattia i terminy (T. 2). Donets'kyı̆ natsional'nyı̆ universytet. 


\section{The Issue of Genre Typology of Terminological Dictionary Reviews}

Summary

This article considers the terminological dictionary review as an integral genre that combines the features of scientific communication, language criticism, source studies, literary studies and publicism.

As stressed, critical sub-discourse is a component of evaluative discourse, and reviews of scientific works are a typical manifestation of evaluative discourse and critical sub-discourse.

A multidimensional genre typology of post-publication reviews of terminological dictionaries is developed on the basis of such features as: the number of authors; the specialities of reviewers; the type of a journal where the review is published; the scope of information in the review; the number of dictionaries under consideration; the type of specialist dictionaries under review; presence/absence of scientific discussion, i.e. presence/absence of a response to the review; the style of the text of the review; the time between the release of the dictionary and the publication of the review.

\section{Problem typologii gatunkowej recenzji słowników terminologicznych}

\section{Streszczenie}

Artykuł definiuje recenzję słownika terminologicznego jako gatunek integralny, łączący w sobie cechy komunikacji naukowej, krytyki językowej, źródłoznawstwa, literaturoznawstwa i publicystyki.

W tekście podkreśla się, że subdyskurs krytyczny jest elementem dyskursu ewaluacyjnego, a recenzja badań naukowych jest typowym przejawem dyskursu ewaluacyjnego i subdyskursu krytycznego. 
Omawia się wieloaspektową typologię recenzji popublikacyjnych słowników terminologicznych, uwzględniając elementy takie jak: liczba autorów; specjalizacja recenzentów; typ czasopisma, w którym zamieszczono recenzję; zakres informacji zawartych w recenzji; liczba omawianych słowników; typ recenzowanych słowników specjalistycznych; obecność/brak dyskusji naukowej, tzn. obecność/brak odpowiedzi na recenzję; styl tekstu recenzji; czas, jaki upłynął między publikacją słownika a pojawieniem się recenzji.

Keywords: genre typology of the review; critical sub-discourse; review features; evaluative discourse; post-publication review; terminological dictionary

Słowa kluczowe: typologia gatunkowa recenzji; subdyskurs krytyczny; cechy recenzji; dyskurs ewaluacyjny; recenzja popublikacyjna; słownik terminologiczny

Tetiana O. Petrova, V. V. Dokuchaev Kharkiv National Agrarian University, Kharkiv, Ukraine ORCID: https://orcid.org/0000-0002-9534-9891

Correspondence: t-petrova@ukr.net

The preparation of this article was self-financed by the author.

Competing interests: The author has declared that she has no competing interests.

Publication history: Received: 2019-12-03; Accepted: 2021-02-01; Published: 2021-11-27 